\title{
Multifunctionality of floodplain landscapes: relating management options to ecosystem services
}

\author{
Stefan Schindler • Zita Sebesvari • Christian Damm • Katrin Euller • \\ Volker Mauerhofer • Anna Schneidergruber • Marianna Biró • Franz Essl • \\ Róbert Kanka $\cdot$ Sophie G. Lauwaars $\cdot$ Christiane Schulz-Zunkel $\cdot$ \\ Theo van der Sluis • Michaela Kropik • Viktor Gasso - Andreas Krug • \\ Martin T. Pusch - Klaus Peter Zulka • Werner Lazowski • Christa Hainz-Renetzeder • \\ Klaus Henle • Thomas Wrbka
}

Received: 21 June 2013/Accepted: 15 January 2014/Published online: 7 February 2014

(C) Springer Science+Business Media Dordrecht 2014

\begin{abstract}
The concept of green infrastructure has been recently taken up by the European Commission for ensuring the provision of ecosystem services (ESS). It aims at the supply of multiple ESS in a given landscape, however, the effects of a full suite of management options on multiple ESS and landscape multifunctionality have rarely been assessed. In this paper we use European floodplain landscapes as example to develop an expert based qualitative conceptual model for the assessment of impacts of landscape scale interventions on multifunctionality. European floodplain landscapes are particularly useful
\end{abstract}

Electronic supplementary material The online version of this article (doi:10.1007/s10980-014-9989-y) contains supplementary material, which is available to authorized users.

S. Schindler $(\bowtie) \cdot$ K. Euller $\cdot$ A. Schneidergruber

F. Essl · M. Kropik - C. Hainz-Renetzeder · T. Wrbka

Department of Conservation Biology, Vegetation \&

Landscape Ecology, University of Vienna, Rennweg 14,

1030 Vienna, Austria

e-mail: stefan.schindler@univie.ac.at

S. Schindler

CIBIO-Centro de Investigação em Biodiversidade e

Recursos Genéticos/InBio, Universidade do Porto,

Campus Agrário de Vairão, Rua Padre Armando Quintas, 4485-661 Vairão, Portugal

\section{Z. Sebesvari}

United Nations University, Institute for Environment and Human Security (UNU-EHS), Platz der Vereinten

Nationen 1, 53113 Bonn, Germany for such approach as they originally provided a high variety and quantity of ESS that has declined due to the strong human impact these landscapes have experienced. We provide an overview of the effects of floodplain management options on landscape multifunctionality by assessing the effects of 38 floodplain management interventions on 21 relevant ESS, as well as on overall ESS supply. We found that restoration and rehabilitation consistently increased the multifunctionality of the landscape by enhancing supply of provisioning, regulation/maintenance, and cultural services. In contrast, conventional technical regulation measures and interventions related to extraction, infrastructure and intensive land use cause decrease in multifunctionality and negative effects for the supply of all three aspects of ESS. The overview of

\section{Damm}

Karlsruhe Institute of Technology (KIT), Institute for Geography and Geoecology, Division WWF-Institute of Floodplain Ecology, Josefstrasse 1, 76437 Rastatt, Germany

\section{Mauerhofer}

United Nations University, Institute of Advanced Studies (UNU-IAS), 6F International Organizations Center Pacifico-Yokohama, 1-1-1 Minato Mirai, Nishi-ku, Yokohama 220-8502, Japan

M. Biró

Centre for Ecological Research, Institute of Ecology and Botany, Hungarian Academy of Sciences, Alkotmány u. 2-4., 2163 Vácrátót, Hungary 
the effects of interventions shall provide guidance for decision makers at multiple governance levels. The presented conceptual model could be effectively applied for other landscapes that have potential for a supply of a high diversity of ESS.

Keywords Multifunctional landscapes · Green infrastructure - Nature conservation .

Environmental management $\cdot$ Multifunctionality index $\cdot$ Hydrological engineering $\cdot$ Restoration . Recreation · Provisioning services · Cultural services

\section{Introduction}

Over the last few decades the demand for natural resources has strongly grown worldwide due to increasing human population size, exponential economic growth and global consumption resulting in an expansion of human settlements and infrastructures, fragmentation and degradation of natural landscapes and an alarming loss of biodiversity and ecosystem services (ESS) (MEA 2005; Butchart et al. 2010; Cardinale et al. 2012). Most ESS arise from living organisms and the interaction of biotic and abiotic processes, and refer specifically to the 'final' outputs from landscapes that provide benefits to humans (Haines-Young et al. 2012; Maes et al. 2012). Human

F. Essl - K. P. Zulka

Environment Agency Austria (EAA), Spittelauer Lände 5, 1090 Vienna, Austria

R. Kanka

Institute of Landscape Ecology, Slovak Academy of

Sciences (ILE SAS), Štefánikova 3, 81499 Bratislava,

Slovakia

S. G. Lauwaars

Rijkswaterstaat, Ministry of Infrastructure and

Environment, Griffioenlaan 2, 3526 LA Utrecht,

The Netherlands

C. Schulz-Zunkel · K. Henle

Department of Conservation Biology, UFZ - Helmholtz

Centre for Environmental Research, Permoserstr. 15,

04318 Leipzig, Germany

T. van der Sluis

Alterra, Wageningen UR, P.O. Box 47,

6700 AA Wageningen, The Netherlands societies tend to value the potential benefits that a landscape might provide in a limited way, adjusting management practices towards desired outputs by maximizing the benefits gained from one or some of the services (often the provision of goods) leading to the loss of multifunctionality and the degradation of natural capital at the expense of human welfare (TEEB 2010; Kettunen and ten Brink 2012). As a result of this biased valuation, the opportunity costs of biodiversity conservation have been perceived as too high (Balvanera et al. 2001).

Multifunctional approaches emphasize opportunities to improve landscapes by increasing spatial heterogeneity through the addition (or conservation) of seminatural landscape elements designed to provide multiple ESS (Lovell and Johnston 2009). One important approach to optimize a balanced supply of multiple ESS in a landscape is the concept of green infrastructure, which is defined as an "interconnected network of green space that conserves natural ecosystem values and functions and provides associated benefits to human populations" (Benedict and MacMahon 2002). While it was mainly developed in the USA, it builds forth in the EU on the Pan European Ecological Network concept (Jongman et al. 2011; van der Sluis et al. 2012), which is also vested in Article 10 of the EU Habitats Directive and aims to overcome the fragmentation of the landscape. The concept has been recently taken up by the European Commission by linking it with policies on adaptation to climate change

V. Gasso

Oles Honchar Dnipropetrovsk National University, Gagarin Avenue 72, Dnipropetrovsk 49010, Ukraine

A. Krug

Federal Agency for Nature Conservation,

Konstantinstraße 110, 53179 Bonn, Germany

M. T. Pusch

Department of Ecosystem Research, Leibniz Institute of Freshwater Ecology and Inland Fisheries, Müggelseedamm 301, 12587 Berlin, Germany

W. Lazowski

Technisches Büro für Ökologie, Kagraner Anger 22/7/2, 1220 Vienna, Austria 
(COM 2009), cohesion (COM 2011b), and biodiversity (COM 2011a), with the last demanding that "by 2020, ecosystems and their services are maintained and enhanced by establishing green infrastructure and restoring at least $15 \%$ of degraded ecosystems". The integration of ESS into accounting and reporting systems at EU and national levels is expected to be completed by 2020 (COM 2011a), and the importance of investing in natural ecosystems, in particular urban green areas, floodplains and sites for recreation, is recognized as a source of economic development in the EUs regional and cohesion policy (COM 2011b). In the short-term, the essential challenge is to gather and operationalize the information and scientific knowledge currently available on ecosystems and their services across Europe (Maes et al. 2012, 2013).

Floodplains of large lowland rivers are suitable landscapes for investigating the impact of management options on multiple ESS and landscape multifunctionality, because the potential for the supply of multiple ESS and the need for sustainable landscape management are particularly high (Tockner and Standford 2002; Nijland and Menke 2005; Delpla et al. 2009; Merz et al. 2009; Scholz et al. 2012; Mueller et al. 2014). Freshwater supply, products from agriculture, fishery and forestry, hydro-power, bioremediation, flood protection, habitat and gene pool protection, and recreational opportunities are often derived ESS, however, management priorities differ strongly among European countries (Schindler et al. 2013b). Located in agricultural and urbanized landscape matrices, floodplains often present natural conservation areas of high value to relevant plant and animal species, ecotourism and recreation, and are acting there as corridors, giving species the opportunity to migrate and disperse through fragmented landscapes (Jongman et al. 2004). At the same time, floodplain landscapes are under threat from increasing human land use pressures (Tockner and Standford 2002; Scholz et al. 2012), and it is supposed that floodplains are particularly vulnerable to climate change impacts and that carefully planned floodplain management is more and more required with growing demand of floodplain ESS under global change (Capon et al. 2013).

Current research on ESS is dealing with their assessment, quantification and mapping (Seppelt et al. 2012; Crossman et al. 2013), and is highlighting the relationship between land cover and ESS (Burkhard et al. 2012; Koschke et al. 2012; Hermann et al. 2014), biodiversity and ESS (Cardinale et al. 2012; Mace et al.
2012), trade-offs among different ESS (Kandziora et al. 2013), and policy impact on ESS (Maes et al. 2013). However, the effects of different human management actions on the supply of ESS have rarely been assessed (Richter and Thomas 2007), although it is assumed that direct human interventions in natural capital are the main culprits for changes in ESS supply (MEA 2005; Kettunen and ten Brink 2012). In this paper we are bridging this gap by developing an expert based qualitative conceptual model for the assessment of impacts of landscape scale interventions on landscape multifunctionality. Implementing the approach for European floodplain landscapes, we provide an overview of the effects of floodplain management options on ESS and multifunctionality, which has been lacking according to our knowledge. For doing so, we (i) defined sets of most relevant floodplain management interventions and most relevant ESS, (ii) assessed the effects of each intervention on each ESS, and (iii) calculated for each intervention a multifunctionality index taking into account the intervention's overall impact on ESS. In this sense, this paper aims to identify management options, which support reaching the targets set by the EU Biodiversity Strategy (COM 2011a).

\section{Methods}

Study approach

A traditional strength of landscape ecology is operationalizing scientific evidence and expert knowledge for policy needs by holistic approaches (Antrop et al. 2013). The complex field of floodplain management involves highly dynamic ecosystems, faced with long term changes in a cross-cultural and cross-border political setting (Moss and Monstadt 2008). This requires holistic solutions based on tradeoffs for instance between environmental quality and safety (Sedell et al. 1989; Geilen et al. 2004; Pettifer and Kay 2012). In this study, we evaluated the effects of floodplain management measures on ESS by an expert based assessment. This approach was motivated by a reported mismatch between the spatial and temporal scale of policy needs and the scattered scientific evidence for the ecological effects of floodplain management and by the need of a stronger consideration of knowledge from experts and practitioners (Bernhardt et al. 2005, 2007; Schindler et al. 2013b). 
Table 1 Floodplain interventions $(n=38)$ grouped into nine types that were included in the assessment

\begin{tabular}{|c|c|c|}
\hline Type of interventions & Intervention & Examples for specific measures and comments \\
\hline \multirow[t]{3}{*}{$\begin{array}{l}\text { 1: Production- } \\
\text { extraction }\end{array}$} & Surface water extraction & $\begin{array}{l}\text { E.g. from the river; e.g. for industries, power plants, human } \\
\text { consumption, navigation, agriculture, aquaculture }\end{array}$ \\
\hline & Groundwater extraction & $\begin{array}{l}\text { E.g. for industries, power plants, human consumption, navigation, } \\
\text { agriculture, aquaculture; incl. establishing pumping wells, } \\
\text { establishing of water protection zones }\end{array}$ \\
\hline & Mineral resource extraction & Clay, sand and gravel extraction \\
\hline \multirow[t]{3}{*}{$\begin{array}{l}\text { 2: Production- } \\
\text { infrastructure }\end{array}$} & $\begin{array}{l}\text { Terrestrial settlement and traffic } \\
\text { infrastructure }\end{array}$ & $\begin{array}{l}\text { Construction, maintenance and usage of houses, industries, } \\
\text { commercial areas; traffic infrastructure, incl. urban sprawl (planned } \\
\text { or unplanned) }\end{array}$ \\
\hline & Energy conversion & Mainly hydro-power (including cooling water release) \\
\hline & Navigational infrastructure & $\begin{array}{l}\text { Navigation, improving navigability of the river, river bed excavation, } \\
\text { establishment of groynes, construction of dams and locks [but not } \\
\text { dikes] }\end{array}$ \\
\hline \multirow[t]{3}{*}{$\begin{array}{l}\text { 3: Production- } \\
\text { intensive land use }\end{array}$} & Forestry intensive & $\begin{array}{l}\text { Forest plantations (including monocultures of native or non-native } \\
\text { spp.), monofunctional forestry, including forestry for biomass } \\
\text { production }\end{array}$ \\
\hline & Agriculture intensive & $\begin{array}{l}\text { Incl. intensive grassland, including crops for bioenergy and biomass } \\
\text { production }\end{array}$ \\
\hline & Fishery intensive & $\begin{array}{l}\text { Extraction of relatively big amounts of fish, fish-stocking, creation of } \\
\text { fish ponds }\end{array}$ \\
\hline \multirow[t]{4}{*}{$\begin{array}{l}\text { 4: Production- } \\
\text { extensive land use }\end{array}$} & Forestry extensive & $\begin{array}{l}\text { Enabling spontaneous forest development (sustainable timber } \\
\text { harvesting without any strong intervention) }\end{array}$ \\
\hline & Agriculture extensive & Incl. multiple uses, small scale grazing, low livestock units per area \\
\hline & Fishery extensive & Placement of spawning gravel, small-scale hobby fishing \\
\hline & Hunting & Game management \\
\hline \multirow{6}{*}{$\begin{array}{l}\text { 5: Hydrological } \\
\text { engineering- } \\
\text { regulation }\end{array}$} & Channel corrections & Straightening, meander-cut off \\
\hline & Dike construction & Building new, reinforce existing dikes \\
\hline & Bank/bed stabilization & Riprap, bed enforcement \\
\hline & Sediment removal/dredging & Incl. non-navigable rivers; including temporal opening of a dam \\
\hline & Detention basins & $\begin{array}{l}\text { Facilities for the retention of storm water in upper or lower courses; } \\
\text { they might be partly natural, partly rather intensively used }\end{array}$ \\
\hline & Controlled retention areas & $\begin{array}{l}\text { E.g. "controlled polders", which can store peak flows, entrance and } \\
\text { release of water is controlled by constructions }\end{array}$ \\
\hline \multirow{5}{*}{$\begin{array}{l}\text { 6: Hydrological } \\
\text { engineering- } \\
\text { rehabilitation }\end{array}$} & Dike relocation & $\begin{array}{l}\text { (Incl. depoldering) - Relocation towards a greater distance from the } \\
\text { river course }\end{array}$ \\
\hline & Ecologically improved groynes & $\begin{array}{l}\text { Incl. lowering groynes, special shaping of groynes to optimize } \\
\text { ecological benefits }\end{array}$ \\
\hline & Lowering floodplain/foreland & \\
\hline & Sediment addition into river bed & To compensate bed load deficit \\
\hline & Removing obstacles & Bridge pylons, road dams etc. \\
\hline \multirow{3}{*}{$\begin{array}{l}\text { 7: Restoration- } \\
\text { connectivity }\end{array}$} & Removal of bank fixations & \\
\hline & Removal of dams and weirs & Reestablishing longitudinal connectivity \\
\hline & $\begin{array}{l}\text { Lateral floodplain reconnection } \\
\text { measures }\end{array}$ & $\begin{array}{l}\text { E.g. reconnecting side channels/oxbows; incl. measures like lowering } \\
\text { of road-dams, lowering maintenance trails, widening of inlet } \\
\text { structures }\end{array}$ \\
\hline
\end{tabular}


Table 1 continued

\begin{tabular}{|c|c|c|}
\hline Type of interventions & Intervention & Examples for specific measures and comments \\
\hline & $\begin{array}{l}\text { Channel, oxbow and pond creation } \\
\text { construction of fish passages }\end{array}$ & Incl. rock ramps and bypasses \\
\hline \multirow[t]{7}{*}{$\begin{array}{l}\text { 8: Restoration- } \\
\text { renaturation }\end{array}$} & $\begin{array}{l}\text { Creation of natural habitat by } \\
\text { transforming forest plantations }\end{array}$ & $\begin{array}{l}\text { Creation of natural habitats in areas that were covered by forest } \\
\text { plantations before the implementation of the interventions }\end{array}$ \\
\hline & $\begin{array}{l}\text { Creation of natural habitat by } \\
\text { transforming agricultural land }\end{array}$ & $\begin{array}{l}\text { Creation of natural habitats in areas that were covered by agricultural } \\
\text { land before the implementation of the interventions }\end{array}$ \\
\hline & $\begin{array}{l}\text { Creation of natural habitat by } \\
\text { transforming extraction sites }\end{array}$ & $\begin{array}{l}\text { Creation of natural habitats in areas that were covered by extraction } \\
\text { sites (e.g. clay-pits, gravel extraction, etc.) before the } \\
\text { implementation of the interventions }\end{array}$ \\
\hline & Control of invasive alien species & $\begin{array}{l}\text { Ringbarking/cutting, biocides application, grazing/mowing, } \\
\text { eradication of invasive alien biota }\end{array}$ \\
\hline & Creation of gravel banks & $\begin{array}{l}\text { For initialization of natural succession (and evtl. gravel breeding } \\
\text { habitats) }\end{array}$ \\
\hline & Removal of top soil & $\begin{array}{l}\text { For initialization of natural succession, e.g. elimination of nutrient- } \\
\text { rich top soil to create conditions for species rich wet meadows }\end{array}$ \\
\hline & Land use extensification & $\begin{array}{l}\text { Reduced intensity of use (mainly agriculture especially grassland, } \\
\text { forestry, hunting and fishery) }\end{array}$ \\
\hline \multirow[t]{2}{*}{ 9: Recreation } & $\begin{array}{l}\text { Establishment, maintenance and } \\
\text { usage of recreational } \\
\text { infrastructure }\end{array}$ & $\begin{array}{l}\text { E.g. construction of footpaths, info centers, access roads, observation } \\
\text { hides, etc. }\end{array}$ \\
\hline & Recreational use of the floodplain & "Off-track", e.g. fishermen, collectors, etc. \\
\hline
\end{tabular}

Given the high biological diversity and heterogeneity of floodplains, it should be of advantage to evaluate management operations by holistic approaches that go beyond targeted indicators (Geist 2011; Pander and Geist 2013; Mueller et al. 2014). Expert based assessments are a commonly used method when assessing relations to or effects on a broad range of ESS in the absence of sufficient data (Burkhard et al. 2009, 2012; Vihervaara et al. 2010; Fagerholm et al. 2012; Koschke et al. 2012; Palomo et al. 2013; Hermann et al. 2014). In this study, scientific evidence, personal expertise, and other sources of knowledge were applied by experts to define a set of most relevant floodplain management interventions, to choose the most appropriate ESS classification scheme, and to evaluate the impact of each floodplain intervention on the supply of each ESS. The selection of experts for this study was conducted by consulting a European Network of Knowledge on Biodiversity and Ecosystem Services (Balian et al. 2012). Selection criteria were expertise on floodplain ecology, floodplain management, and ESS, geographical coverage, independence among experts, and the need for balanced scientific and institutional profiles of the expert team consisting of researchers, water and conservation managers and policy makers (Palomo et al. 2013; Schindler et al. 2013b). In total, 21 experts from six European countries participated in this assessment (see Table S1 in the Supplementary Material for their background and expertise) and shared authorship of this paper. Required group discussions where first facilitated at a workshop and later by a series of teleconferences.

\section{Relating interventions to ESS}

As first steps, we agreed on considering rivers and their floodplains as functional units and to focus on floodplains of large rivers in Central Europe, such as the Danube, Dnieper, Rhine, Vistula, Tisza, Meuse and Oder. 38 typical floodplain interventions were defined as a set of specific measures with similar aims and similar consequences in terms of expected ESS supply and demand (Table 1). The interventions included, for instance, change of land use intensity, removal of river bank fixation, elongation of river length, creation of new water courses and multiple channels, and reconnection of backwaters (Lorenz et al. 2012). The 38 interventions were categorized into nine types according to their main management purpose (Table 1). 
For the classification and definition of ESS, we applied the Common International Classification of Ecosystem Services (CICES; Haines-Young and Potschin 2013). CICES has been proposed for ecosystem assessments and valuation in the frame of the European Biodiversity Strategy by the Working Group on Mapping and Assessment on Ecosystems and their Services (MAES) (Maes et al. 2012).
In this classification special care was taken to avoid double counting (i.e. considering a service provided by nature under two or more ESS categories) and therefore it is particularly suitable for summarizing the different ESS. We used 21 ESS of the CICESclassification for our assessment (Table 2) only excluding the services related to marine environments.

Table 2 ESS considered in the assessment on the basis of CICES (from Haines-Young and Potschin 2013)

\begin{tabular}{|c|c|}
\hline Ecosystem service & Details \\
\hline \multicolumn{2}{|l|}{ Provisioning services } \\
\hline Terrestrial plants and animals for food & Crops, livestock and dairy farming, wild plants and animals and their products \\
\hline $\begin{array}{l}\text { Freshwater plants and animals for } \\
\text { food }\end{array}$ & Fish (wild populations), aquaculture products, fresh water plants \\
\hline Water for human consumption & Drinking water, domestic water use \\
\hline Water for agricultural use & $\begin{array}{l}\text { Irrigation water (consumptive) e.g. for crop production, water for livestock (consumptive) } \\
\text { e.g. ponds }\end{array}$ \\
\hline Water for industrial and energy uses & Industrial water, cooling water (e.g. for power production) \\
\hline Biotic materials & $\begin{array}{l}\text { Non-food vegetal fibers, non-food animal fibers, ornamental resources (e.g. bulbs, pearls, } \\
\text { cut flowers), genetic resources (e.g. wild species used in breeding programs), medicinal } \\
\text { and cosmetic resources }\end{array}$ \\
\hline Biomass based energy & Vegetal based resources (e.g. energy crops), animal based resources (e.g. fat) \\
\hline \multicolumn{2}{|l|}{ Regulation and maintenance } \\
\hline Bioremediation & $\begin{array}{l}\text { Remediation by plants or algae, remediation by micro-organisms, remediation by animals } \\
\text { (e.g. filtration of particles using mollusks) }\end{array}$ \\
\hline Air flow regulation & $\begin{array}{l}\text { Rural microclimatic regulation (e.g. natural or planted vegetation that serves as shelter } \\
\text { belts), urban microclimatic regulation (e.g. ventilation) }\end{array}$ \\
\hline Water flow regulation & $\begin{array}{l}\text { Attenuation of runoff and discharge rates (e.g. woodlands), water storage for flow } \\
\text { regulation (e.g. flood plains and wetlands), coastal protection (e.g. mangroves, sea } \\
\text { grasses) }\end{array}$ \\
\hline Mass flow regulation & Erosion protection, avalanche and gravity flow protection (e.g. stabilization of mudflows) \\
\hline Atmospheric regulation & Global climate regulation (incl. C-sequestration), local \& regional climate regulation \\
\hline Water quality regulation & $\begin{array}{l}\text { Water purification and oxygenation (e.g. natural or planted vegetation that serves nutrient } \\
\text { retention) }\end{array}$ \\
\hline $\begin{array}{l}\text { Pedogenesis and soil quality } \\
\text { regulation }\end{array}$ & $\begin{array}{l}\text { Maintenance of soil fertility (e.g. N-fixing plants), maintenance of soil structure (e.g. soil } \\
\text { organism activity) }\end{array}$ \\
\hline $\begin{array}{l}\text { Lifecycle maintenance, habitat and } \\
\text { gene pool protection }\end{array}$ & Pollination, seed dispersal, maintaining nursery populations (e.g. habitat refuges) \\
\hline $\begin{array}{l}\text { Pest and disease control (incl. invasive } \\
\text { alien species) }\end{array}$ & Biological control mechanisms \\
\hline \multicolumn{2}{|l|}{ Cultural services } \\
\hline Aesthetic, heritage & $\begin{array}{l}\text { Landscape character (e.g. areas of outstanding natural beauty), cultural landscapes (e.g. } \\
\text { sense of place) }\end{array}$ \\
\hline Spiritual & Wilderness, naturalness (e.g. tranquility), sacred places or species \\
\hline Recreation and community activities & $\begin{array}{l}\text { Charismatic or iconic wildlife or habitats, prey for hunting, fishing or collecting, landscape } \\
\text { character for recreational opportunities (e.g. canoeing, hiking) }\end{array}$ \\
\hline Information and knowledge & Scientific, educational \\
\hline
\end{tabular}


The assessment related each of the 38 interventions to each of the 21 ESS. We consulted about the expected effect of an intervention on ESS in typical floodplains of temperate Europe and to finally agree on one of the following four options: (i) 'no effect', i.e. under most conditions there will not be any significant effect of the intervention on the delivery of the specific ESS or potential effects are currently unknown; (ii) 'negative effect', i.e. under most conditions there will be a negative effect of the intervention on the delivery of the specific ESS; (iii) 'positive effect', i.e. under most conditions there will be a positive effect of the intervention on the delivery of the specific ESS; or (iv) 'ambiguous effect', i.e. negative or positive effects are possible depending on specific conditions. Each of the 21 ESS involved several subservices (e.g., the ESS 'Terrestrial plants and animals for food' involved crops, livestock and dairy farming, wild plants and animals and their products; cf. Table 2). We considered both the quantity and diversity of these subservices when doing the evaluation, and compared the capacity of the floodplain to supply them before and after the implementation of an intervention. For each combination of intervention and ESS, on average $4.1( \pm 1.1 \mathrm{SD}$, range 3-6) experts were involved. For transparency and reproducibility, each judgment was supplemented by a concise statement on the most important reasons for the decision by the experts (Table S2 in the Supplementary Material). After the first draft of the overview of the assessment was completed, selected experts improved completeness of argumentation and consistency of judgments and arguments.

Assessing the effect of the interventions on floodplain multifunctionality

For assessing the impact of interventions on the multifunctionality of floodplains we calculated for each intervention a multifunctionality index by dividing the difference of the number of positively and negatively affected ESS by the total number of considered ESS. ESS that were not affected or effects were judged as ambiguous were accounted for in the 'total number of considered ESS'. Thus, the index ranged between -1 (all ESS were negatively affected) and +1 (all ESS were positively affected), and received the value of \pm 0 when the number of positively affected ESS equaled the number of negatively affected ones. Interventions causing more positively than negatively affected ESS obtain positive values of the multifunctionality index. They are supposed to increase the multifunctionality of the landscape, due to a larger variety of ESS provided as a result of the interventions. We calculated the multifunctionality index separately for all 38 interventions and additionally averaged results across interventions of the same type. Furthermore, we calculated the index considering all 21 ESS but also considered separately each of the three aspects provisioning, regulation/ maintenance, and cultural services (Maes et al. 2012) to assess and compare specific effects of the interventions (cf. De Groot et al. 2010; Hermann et al. 2014). All ESS were treated equally at this stage as our main aim was to provide a generic overview about the impact of management interventions on ESS and floodplain multifunctionality. However, the applied approach can be modified for specific floodplain landscapes by including site specific information including weights for ESS according to their local demand or value.

\section{Results}

Effects of interventions on ESS

and multifunctionality of floodplains

The expert assessment resulted in 798 judgments on effects of interventions on ESS (Table 3). Overall, in $29.3 \%$ of the cases there was no effect of the interventions, in $31.2 \%$ their effect was negative, in $28.3 \%$ positive, and in $11.2 \%$ ambiguous. Per ESS, on average $11.1 \pm 6.5$ (mean $\pm \mathrm{SD}$ ) of the 38 interventions had no effect, $11.9 \pm 3.8$ interventions had negative, $10.8 \pm 3.3$ positive, and $4.2 \pm 4.0$ ambiguous effects. The amount of ESS affected in any direction differed largely among the interventions, for instance, recreational use of the floodplain and ecologically improved groynes affected on very few ESS. We detected a low variation of effects within types of interventions, but large differences among them (Fig. 1). The intervention types 'hydrological engineering-rehabilitation', 'restoration-connectivity', and 'restoration-renaturation' (cf. Table 1) had a clear positive impact, whereas 'production-infrastructure' and 'production-intensive land use' had the most negative effects on multifunctionality. The intervention types 'production-extraction' and 'hydrological engineering- 


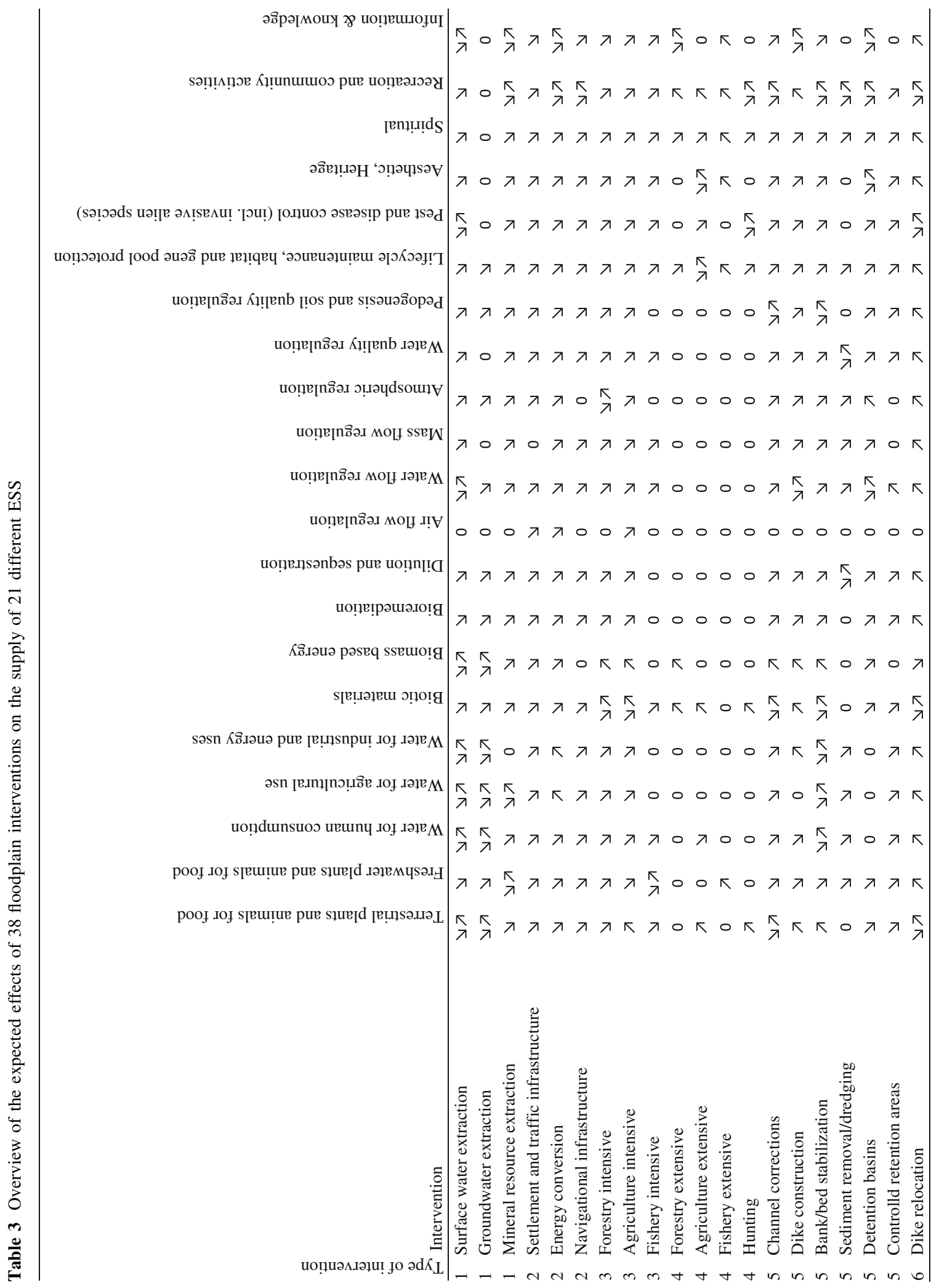




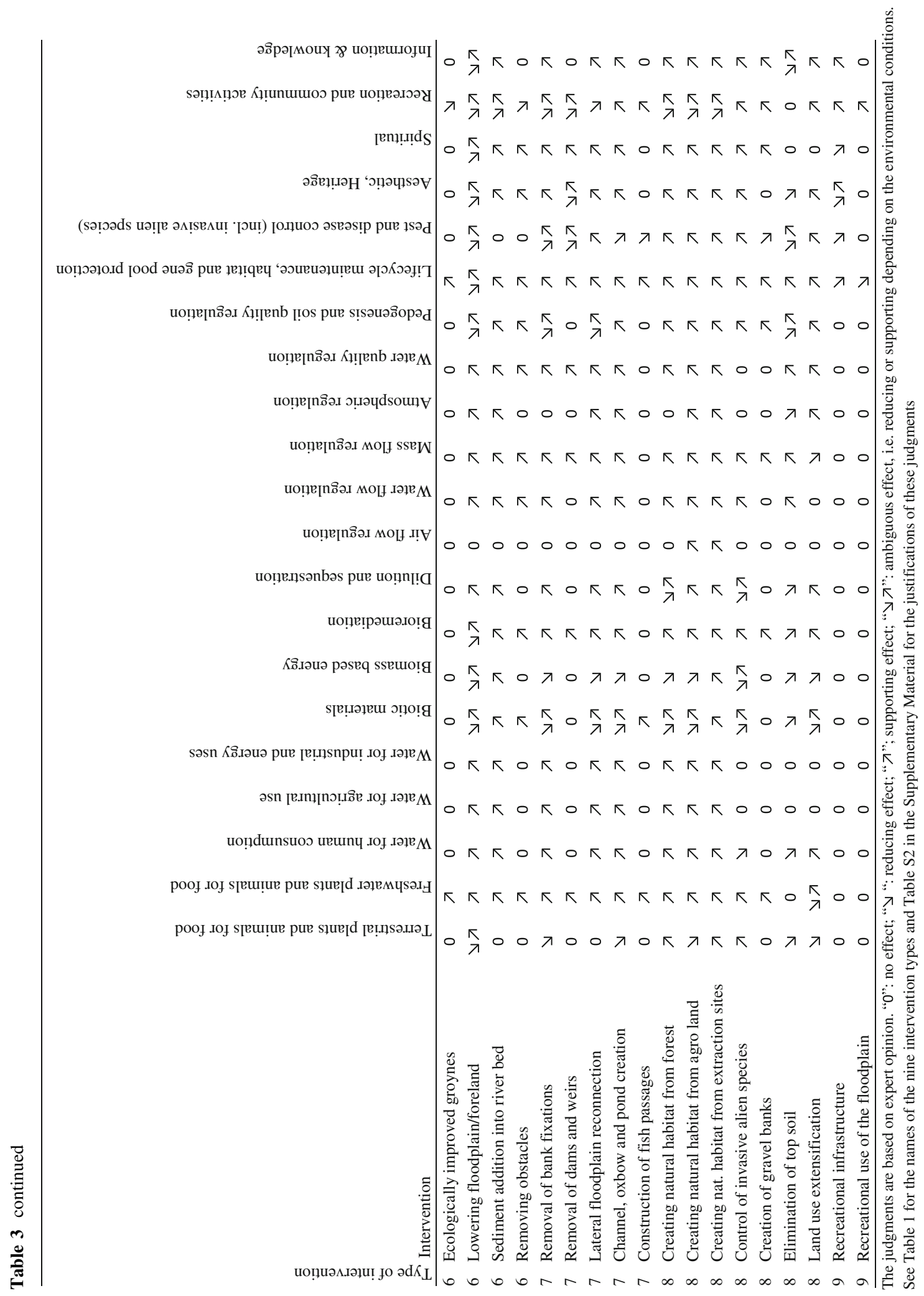




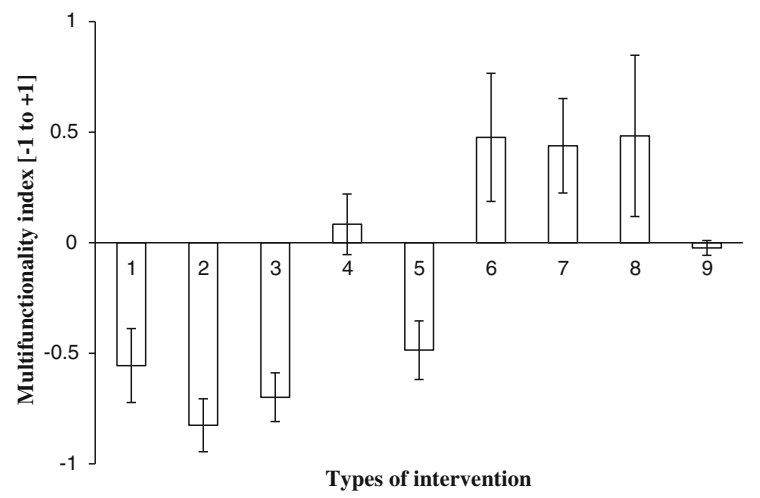

Fig. 1 Effect of the nine intervention types on the multifunctionality of floodplains. 1 Production-extraction, 2 production-infrastructure, 3 production-intensive land use, 4 production-extensive land use, 5 hydrological engineeringregulation, 6 hydrological engineering - rehabilitation, 7 restoration-connectivity, 8 restoration-renaturation, 9 recreation

regulation' had a pronounced but less negative effect whereas the overall effects of 'production-extensive land use' and 'recreation' were marginal.

In more detail, interventions with the most positive effects were related to the creation of natural habitat, dike relocation, lateral floodplain reconnection, creation of channels, oxbows and ponds, whereas the interventions terrestrial settlement and transportation infrastructure, navigational infrastructure, and intensive forms of agriculture, forestry and fisheries are rather problematic when preserving multifunctionality in floodplains (Table 4). Interventions such as surface water, groundwater, and mineral extraction showed no positive effect on any ESS. Adding sediment into the river bed obtained the highest values of the intervention type 'hydrological engineering-rehabilitation', where other measures such as detention basins or controlled retention areas had clearly negative overall effects.

Effects of interventions on provisioning, regulation/maintenance and cultural services

The effect of the interventions on the supply of different ESS aspects, i.e. provisioning, regulation/maintenance, and cultural services, clearly differed among the types of interventions (Fig. 2). 'Production-infrastructure', 'hydrological engineering-rehabilitation' and 'restoration-connectivity' had a similar impact on all three ESS aspects whereas the intervention types 'productionintensive land use', 'hydrological engineering-regulation' and 'restoration-renaturation', resulted in varying effects among the three ESS aspects. For instance, 'restoration-renaturation' had strong positive impacts on cultural and regulation services while provisioning services obtained fewer (but still some) benefits from these interventions. However, several intervention types caused win-win-win or lose-lose-lose situations in terms of ESS for provision, regulation/maintenance, and culture. For instance, restoration measures (intervention types 7 and 8) lead to enhanced values of multifunctionality and average ESS supply for all three aspects. The effect was strongest in respect to cultural and regulation/maintenance services; however, effects were also clearly positive for provisioning services. Contrary, 'production-extraction', 'production-infrastructure' and 'production-intensive land use' obtained low multifunctionality values for all three aspects of ESS, including for provisioning services.

\section{Discussion}

Multifunctional floodplain landscapes and restoration of ESS

Floodplain landscapes are unique as they are indispensable for the provision of a variety of crucial ESS. In addition, in densely populated Europe, most floodplain landscapes have been heavily transformed, and, as recent floods have shown, their capacity to provide ESS has been reduced (Solín et al. 2011; Heintz et al. 2012). Accordingly, enhancing the restoration of ESS has become a top priority in environmental policy in Europe that can only be achieved by using holistic and catchment-oriented approaches (COM 2007, 2011a). In this study, we provide an overview on the effects of a complete set of floodplain interventions on all relevant ESS. We found that interventions related to ecosystem restoration showed positive overall effects, while those related to production and conventional technical river regulation showed negative overall effects on the supply of ESS. Surprisingly, our results were remarkably robust across the different grouping levels of floodplain management options, i.e. the 38 interventions and the 9 types of interventions. Our results are consistent with studies investigating effects on specific ESS, such as bioremediation, dilution and sequestration, and carbon sequestration (Jenkins et al. 2010; Hoffmann et al. 
Table 4 Multifunctionality index of the types of floodplain management interventions calculated for provisioning services $(n=7)$, regulation/maintenance services $(n=10)$, cultural services $(n=4)$ and overall index $(n=21)$

\begin{tabular}{|c|c|c|c|c|c|}
\hline $\begin{array}{l}\text { Intervention } \\
\text { type }\end{array}$ & Intervention & $\begin{array}{l}\text { Provisioning } \\
\text { services }\end{array}$ & $\begin{array}{l}\text { Regulation/maintenance } \\
\text { services }\end{array}$ & $\begin{array}{l}\text { Cultural } \\
\text { services }\end{array}$ & $\begin{array}{l}\text { Overall (all } 21 \\
\text { ESS) }\end{array}$ \\
\hline 1 & Surface water extraction & -0.29 & -0.70 & -0.75 & -0.57 \\
\hline 1 & Groundwater extraction & -0.29 & -0.60 & 0.00 & -0.38 \\
\hline 1 & Mineral resource extraction & -0.57 & -0.90 & -0.50 & -0.71 \\
\hline 2 & Settlement and traffic infrastructure & -1.00 & -0.90 & -1.00 & -0.95 \\
\hline 2 & Energy conversion & -0.43 & -1.00 & -0.50 & -0.71 \\
\hline 2 & Navigational infrastructure & -0.86 & -0.80 & -0.75 & -0.81 \\
\hline 3 & Forestry intensive & -0.57 & -0.80 & -1.00 & -0.76 \\
\hline 3 & Agriculture intensive & -0.29 & -1.00 & -1.00 & -0.76 \\
\hline 3 & Fishery intensive & -0.43 & -0.50 & -1.00 & -0.57 \\
\hline 4 & Forestry extensive & 0.29 & -0.10 & 0.00 & 0.05 \\
\hline 4 & Agriculture extensive & 0.14 & -0.10 & 0.00 & 0.00 \\
\hline 4 & Fishery extensive & 0.14 & 0.10 & 1.00 & 0.29 \\
\hline 4 & Hunting & 0.29 & -0.10 & -0.25 & 0.00 \\
\hline 5 & Channel corrections & -0.43 & -0.80 & -0.75 & -0.67 \\
\hline 5 & Dike construction & 0.29 & -0.80 & -0.25 & -0.33 \\
\hline 5 & Bank/bed stabilization & 0.14 & -0.80 & -0.75 & -0.48 \\
\hline 5 & Sediment removal/dredging & -0.57 & -0.40 & -0.25 & -0.43 \\
\hline 5 & Detention basins & -0.57 & -0.60 & -0.25 & -0.52 \\
\hline 5 & Controlled retention areas & -0.86 & -0.50 & -0.75 & -0.67 \\
\hline 6 & Dike relocation & 0.43 & 0.80 & 0.75 & 0.67 \\
\hline 6 & Ecologically improved groynes & 0.14 & 0.10 & -0.25 & 0.05 \\
\hline 6 & Lowering floodplain/foreland & 0.57 & 0.50 & 0.00 & 0.43 \\
\hline 6 & Sediment addition into river bed & 0.86 & 0.80 & 0.75 & 0.81 \\
\hline 6 & Removing obstacles & 0.29 & 0.60 & 0.25 & 0.43 \\
\hline 7 & Removal of bank fixations & 0.29 & 0.60 & 0.75 & 0.52 \\
\hline 7 & Removal of dams and weirs & 0.14 & 0.40 & 0.25 & 0.29 \\
\hline 7 & Lateral floodplain reconnection & 0.43 & 0.80 & 0.50 & 0.62 \\
\hline 7 & Channel, oxbow and pond creation & 0.29 & 0.70 & 1.00 & 0.62 \\
\hline 7 & Construction of fish passages & 0.29 & 0.00 & 0.25 & 0.14 \\
\hline 8 & Creating natural habitat from forest & 0.57 & 0.70 & 0.75 & 0.67 \\
\hline 8 & $\begin{array}{l}\text { Creating natural habitat from } \\
\text { agricultural land }\end{array}$ & 0.29 & 1.00 & 0.75 & 0.71 \\
\hline 8 & $\begin{array}{l}\text { Creating natural habitat from } \\
\text { extraction sites }\end{array}$ & 1.00 & 1.00 & 0.75 & 0.95 \\
\hline 8 & Control of invasive alien species & 0.14 & 0.60 & 1.00 & 0.52 \\
\hline 8 & Sediment addition & 0.14 & 0.30 & 0.75 & 0.33 \\
\hline 8 & Elimination of top soil & -0.57 & 0.10 & -0.25 & -0.19 \\
\hline 8 & Land use extensification & -0.14 & 0.60 & 0.75 & 0.38 \\
\hline 9 & Recreational infrastructure & 0.00 & -0.20 & 0.25 & -0.05 \\
\hline 9 & Recreational use of the floodplain & 0.00 & -0.10 & 0.25 & 0.00 \\
\hline
\end{tabular}

See Table 1 for the names of the nine intervention types 


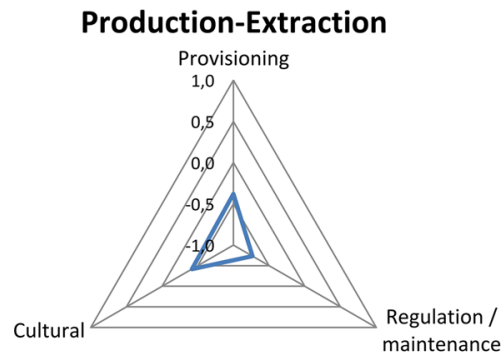

Production-Extensive land use
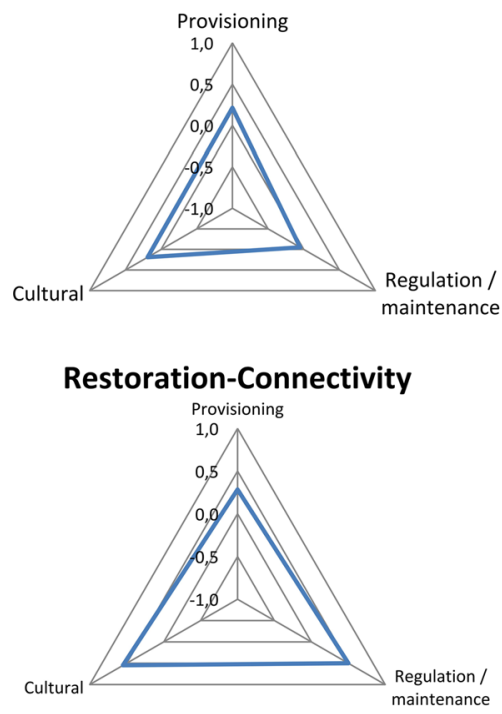
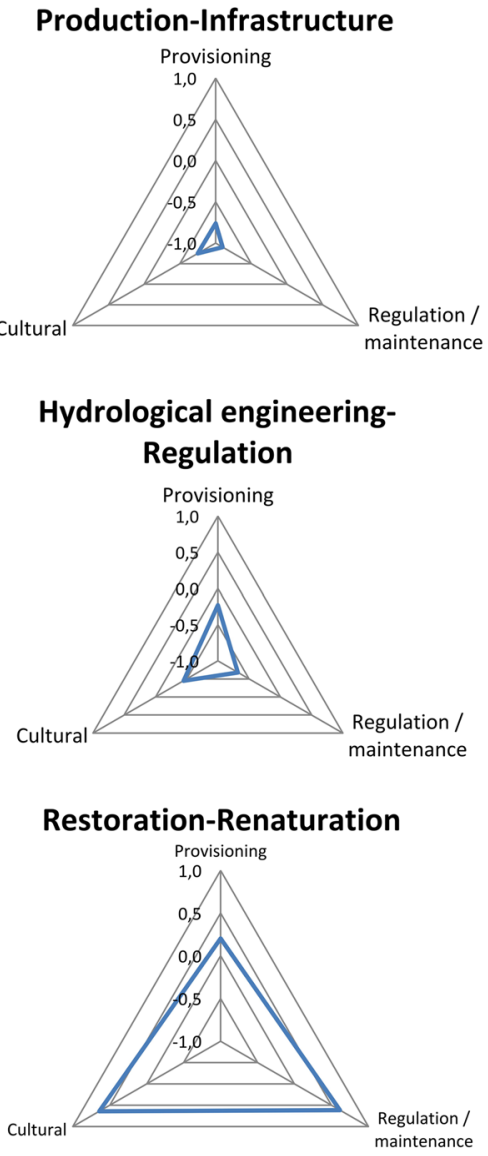
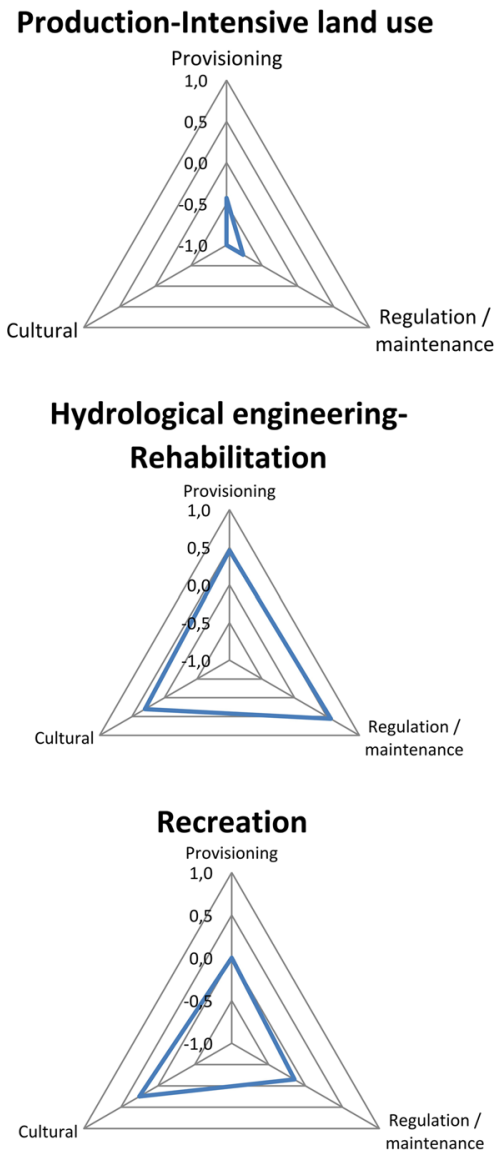

Fig. 2 Impact of nine intervention types on the supply of provisioning, regulation/maintenance, and cultural services. Shown is the average net change of all interventions per type as multifunctionality index. This index ranges between -1 (all

2011; Welti et al. 2011). Regards sediment addition Mueller et al. (2014) confirmed very recently our judgment of positive effects on habitat and gene pool protection.

A focus on restoration of ecosystems and their services should have several general advantages for human societies (Nelson et al. 2009; Rey Benayas et al. 2009; Palmer and Filoso 2009). Trade-offs with biodiversity conservation should be few, because restoration measures that enhance ESS in most cases positively affect biodiversity (Nelson et al. 2009; Rey Benayas et al. 2009). In a meta-analysis on the effects of restoration, Rey Benayas et al. (2009) found that restoration measures often have positive effects on biodiversity and most other ESS except provisioning services, where negative effects, albeit non-significant
ESS are negatively affected) and +1 (all ESS are positively affected), a value of \pm 0 indicates no net change. Thus, small triangles indicate lose-lose situations and large triangles winwin situations

emerged. This difference between their and our results with respect to provisioning services might be caused by our consideration of the diversity of the supplied ESS, both when doing the judgment for a specific ESS, and when summing up all services by means of the multifunctionality index without any weighting procedure. For instance, in our assessment creation of natural habitat from forest plantations leads to a decrease in the quantity of biomaterials due to a loss of high timber yields, but has positive effects on the diversity of the biomaterials supplied. It also has positive effects on the supply of terrestrial and aquatic food, and water resources, causing a positive effect of this restoration measure on provisioning services.

Assessing effects on ESS by expert knowledge faces methodological limitations. In particular, possibilities 
for providing quantitative results are limited. In addition, to ensure reproducibility, the consensus strategy applied needs to be well-documented, and the same holds true for assessment outcomes (cf. Table S2 in the Supplementary material). Finally, the composition of the expert group should reflect the thematic breadth of the scope of the assessment in a balanced way. In the context of highly interconnected floodplain landscapes and the large variety of possible interventions the methodological approach of an expert assessment based on the expertise from researchers and practitioners of several European countries provided useful insights into this complexity. Schindler et al. (2013a) have been conducting a systematic review on the effects of floodplain interventions on biodiversity, and reached the conclusion that the mismatch in spatial and temporal scales between the scattered scientific evidence and the needs of decision-makers calls for a more holistic approach (Schindler et al. 2013b). This demand holds true even more for this overview on the effects of the interventions on all relevant ESS. The expert assessment applied here, allowed for the identification of possible impacts and provides a good basis for the exploration of tradeoffs. It can be modified for specific floodplain landscapes by including site specific information including weights for ESS according to their local demand or value. Burkhard et al. (2012) and Hermann et al. (2014) have shown that expert-based assessments of a broad spectrum of ESS can lead to spatially explicit results and direct implications for local and regional environmental management. However, we believe that our conceptual model can be of advantage compared to the expert-based matrices applied by this authors that relate land cover to multiple ESS. By directly assessing the effects of interventions, our approach is independent judging management options of decision makers and the produced overview can be directly applied as decision support tool.

Recommendations for environmental management

While restoration aiming at multifunctional landscapes and an optimized provision of multiple ESS is an overarching goal of environmental management and landscape planning, it should be assured that the priority remains on protecting the multifunctionality of natural floodplain landscapes. Restored landscapes provide significantly more ESS than unrestored degraded landscapes, but do not reach the level of intact reference landscapes (Rey Benayas et al. 2009). In the approach of optimizing the supply of ESS, we need to better understand the functioning of natural floodplain ecosystems, as they are important reference systems for understanding and learning and can guide conservation efforts (Van der Sluis et al. 2003; Angelstam et al. 2011). In particular, the lateral and longitudinal relationships (Sedell et al. 1989; Jongman et al. 2004; Scholz et al. 2005), the impact of interventions in upstream river sections on those further downstream, and finally on the total ESS require in-depth knowledge and understanding of such complex ecosystems (Scholz et al. 2012). Natural floodplain landscapes, mainly dominated by forests, might supply less terrestrial food or recreation opportunities than restored multifunctional floodplains. However, for practical purposes, supply and demand of ESS are best evaluated in a spatially explicit way (Burkhard et al. 2012) and wise use of floodplain management concepts should involve multifunctional practices at strategic locations and times across landscapes (Werners et al. 2009; Dosskey et al. 2012).

In densely populated Europe a substantial fraction of former floodplain areas has been converted to builtup areas or used for infrastructure. These areas will mostly be unavailable for interventions with the greatest benefit for multifunctionality (Scholz et al. 2005; Werners et al. 2009). However, ensuring the multi-functionality of landscapes was also identified as a key concept for solving resource use conflicts (Seppelt et al. 2009). Where not constrained by existing high value infrastructure, multifunctional land use, sometimes based on the revival of traditional practices, may have a major role in framing people's attitude. Increasing costs of flood damage are currently causing a change in water management strategies which have started to shift toward integrated planning and management approaches, making use of ESS that are only provided by multifunctional riverine landscapes (Pahl-Wostl 2006; Schindler et al. 2013b).

\section{Conclusions}

Floodplains of large European lowland rivers are landscapes where supply and demand of multiple ESS is particularly high. River and floodplain management practices aiming at production, regulation, restoration 
or recreation have all the potential to alter the spatial distribution and supply of ESS on local and regional levels. We found that restoration and rehabilitation measures strongly improved the multifunctionality of the landscape and caused win-win situations for enhancing overall ESS supply for all regulation/ maintenance and cultural services, but also for provisioning services. Conventional regulation but also interventions related to extraction, infrastructure and intensive land use caused lose-lose situations with decreases in multifunctionality and negative effects for the average supply of all three aspects of ESS. The specific interventions creation of natural habitat from extraction sites yielded best results, whereas settlement and traffic infrastructure scored worst.

In the absence of quantitative studies on impacts of interventions on ESS in a given spatial and ecological context (e.g. floodplains), using well-documented consensus expert based approaches are a promising instrument for conceptualizing the impacts of different intervention measures on ESS. Further research should include the development of specific indicators for ESS in floodplain areas and the generation of long-term data sets to study quantitatively the effects of different interventions on ESS supply. Spatially explicit quantifications of supply, demand and trade-off of ESS could be derived from such research, which would enable evidence-based priorizations of local management options and mark an important step towards optimized multifunctional floodplain management. The approach developed in this study can easily be modified for specific floodplain landscapes by including site specific information including weights for ESS according to their local demand or value.

Acknowledgments This research was funded by the European Commission under FP7 as coordination action KNEU "Developing a Knowledge Network for EUropean expertise on biodiversity and ecosystem services to inform policy making economic sectors" (Grant No. 265299). RK was partly funded by the Slovak Research and Development Agency (project number APVV-0866-12). We are grateful to Sandrina Rodrigues for her linguistic improvements.

\section{References}

Angelstam P, Axelsson R, Elbakidze M, Laestadius L, Lazdinis M, Nordberg M, Pătru-Stupariu I, Smith M (2011) Knowledge production and learning for sustainable forest management on the ground: Pan-European landscapes as a time machine. Forestry 84:581-596

Antrop M, Brandt J, Loupa-Ramos I, Padoa-Schioppa E, Porter J, Van Eetvelde V, Pinto-Correia T (2013) How landscape ecology can promote the development of sustainable landscapes in Europe: the role of the European Association for Landscape Ecology (IALE-Europe) in the twenty-first century. Landscape Ecol 28:1641-1647

Balian E, Berhault A, Jones-Walters L, Torre-Marin A, NeBhöver C, Vandewalle M (2012) Overview of experts and requesters of a potential NoK: mapping knowledge holders, identifying requesters and barriers on how to link them. Deliverable 1.1 of the EU-FP7-project KNEU. http:// www.biodiversityknowledge.eu/images/Documents/ Deliverables/KNEU-D1-1_clientsandholdersoverviewand barriers_Final.pdf

Balvanera P, Daily GC, Ehrlich PR, Ricketts TH, Bailey SA, Kark S, Kremen C, Pereira H (2001) Conserving biodiversity and ecosystem services. Science 291:2047

Benedict MA, MacMahon ET (2002) Green infrastructure: smart conservation for the 21 st century. Renew Res J 20:12-17

Bernhardt ES, Palmer MA, Allan JD, Alexander G, Barnas K, Brooks S, Carr J, Clayton S, Dahm C, Follastad-Shah J, Galat D, Gloss S, Goodwin P, Hart D, Hassett B, Jenkinson R, Katz S, Kondolf GM, Lake PS, Lave R, Meyer JL, O'Donnell TK, Pagano L, Powell B, Sudduth E (2005) Synthesizing U.S. river restoration efforts. Science 308:636-637

Bernhardt ES, Sudduth EB, Palmer MA, Allan JD, Meyer JL, Alexander G, Follastad-Shah J, Hassett B, Jenkinson R, Lave R, Rumps J, Pagano L (2007) Restoring rivers one reach at a time: results from a survey of US river restoration practitioners. Restor Ecol 15:482-493

Burkhard B, Kroll F, Müller F, Windhorst W (2009) Landscapes' capacities to provide ecosystem services-a concept for land-cover based assessments. Landscape Online 15:1-22

Burkhard B, Kroll F, Nedkov S, Müller F (2012) Mapping supply, demand and budgets of ecosystem services. Ecol Indic 21:17-29

Butchart SHM, Walpole M, Collen B, van Strien A, Scharlemann JPW, Almond REA, Baillie JEM, Bomhard B, Brown C, Bruno J, Carpenter KE, Carr GM, Chanson J, Chenery AM, Csirke J, Davidson NC, Dentener F, Foster M, Galli A, Galloway JN, Genovesi P, Gregory RD, Hockings M, Kapos V, Lamarque J-F, Leverington F, Loh J, McGeoch MA, McRae L, Minasyan A, Hernández Morcillo M, Oldfield TEE, Pauly D, Quader S, Revenga C, Sauer JR, Skolnik B, Spear D, Stanwell-Smith D, Stuart SN, Symes A, Tierney M, Tyrrell TD, Vié J-C, Watson R (2010) Global biodiversity: indicators of recent declines. Science 328:1164-1168

Capon SJ, Chambers LE, Mac Nally R, Naiman RJ, Davies P, Marshall N, Pittock J, Reid M, Capon T, Douglas M, Catford J, Baldwin DS, Stewardson M, Roberts J, Parsons M, Williams SE (2013) Riparian ecosystems in the 21st century: hotspots for climate change adaptation? Ecosystems 16:359-381

Cardinale BJ, Duffy JE, Gonzalez A, Hooper DU, Perrings C, Venail P, Narwani A, Mace GM, Tilman D, Wardle DA, 
Kinzig AP, Daily GC, Loreau M, Grace JB, Larigauderie A, Srivastava D, Naeem S (2012) Biodiversity loss and its impact on humanity. Nature 486:59-67

COM (2007) Directive 2007/60/EC of the European Parliament and the Council of 23 October 2007 on the assessment and management of flood risks. Off. J. Eur. Union 2007, L288/ 27-L288/34

COM (2009) Adapting to climate change: towards a European framework for action. European Commission, Brussels. COM 147, 2009. http://eur-lex.europa.eu/LexUriServ/ LexUriServ.do?uri=COM:2009:0147:FIN:EN:PDF

COM (2011a) Our life insurance, our natural capital: an EU biodiversity strategy to 2020, Brussels. COM 244, 2011. http://ec.europa.eu/environment/nature/biodiversity/ comm2006/pdf/2020/1_EN_ACT_part1_v7\%5B1\%5D.pdf

COM (2011b) Regional policy contributing to sustainable growth in Europe 2020. European Commission, Brussels. COM 17, 2011. http://ec.europa.eu/regional_policy/sources/docoffic/ official/communic/sustainable/comm2011_17_en.pdf

Crossman ND, Burkhard B, Nedkov S, Willemen L, Petz K, Palomo I, Drakou EG, Martín-Lopez B, McPhearson T, Boyanova K, Alkemade R, Egoh B, Dunbar MB, Maes J (2013) A blueprint for mapping and modelling ecosystem services. Ecosyst Serv 4:4-14

De Groot RS, Alkemade R, Braat L, Hein L, Willemen L (2010) Challenges in integrating the concept of ecosystem services and values in landscape planning, management and decision making. Ecol Complex 7:260-272

Delpla I, Jung A-V, Baures E, Clement M, Thomas O (2009) Impacts of climate change on surface water quality in relation to drinking water production. Environ Int 35:1225-1233

Dosskey M, Wells G, Bentrup G, Wallace D (2012) Enhancing ecosystem services: designing for multifunctionality. J Soil Water Conserv 67(2):37A-41A

Fagerholm N, Käyhkö N, Ndumbaro F, Khamis M (2012) Community stakeholders' knowledge in landscape assessments-mapping indicators for landscape services. Ecol Indic 18:421-433

Geilen N, Jochems H, Krebs L, Muller S, Pedroli B, van der Sluis T, van Looy K, van Rooij S (2004) Integration of ecological aspects in flood protection strategies: defining and ecological minimum. River Res Appl 20:269-283

Geist J (2011) Integrative freshwater ecology and biodiversity conservation. Ecol Indic 11:1507-1516

Haines-Young R, Potschin M (2013) Common International Classification of Ecosystem Services (CICES): Consultation on Version 4, August-December 2012. EEA Framework Contract No EEA/IEA/09/003

Haines-Young R, Potschin M, Kienast F (2012) Indicators of ecosystem service potential at European scales: mapping marginal changes and trade-offs. Ecol Indic 21:39-53

Heintz MD, Hagemeier-Klose M, Wagner K (2012) Towards a risk governance culture in flood policy-findings from the implementation of the "Floods Directive" in Germany. Water 4(1):135-156

Hermann A, Kuttner M, Hainz-Renetzeder C, Konkoly-Gyuró É, Tirászi Á, Brandenburg C, Allex B, Ziener K, Wrbka T (2014) Assessment framework for landscape services in European cultural landscapes: an Austrian Hungarian case study. Ecol Indic 37(A):229-240
Hoffmann CC, Kronvang B, Audet J (2011) Evaluation of nutrient retention in four restored Danish riparian wetlands. Hydrobiologia 674:5-24

Jenkins WA, Murray BC, Kramer RA, Faulkner SP (2010) Valuing ecosystem services from wetlands restoration in the Mississippi Alluvial Valley. Ecol Econ 69:1051-1061

Jongman RHG, Külvik M, Kristiansen I (2004) European ecological networks and greenways. Landscape Urban Plan 68:305-319

Jongman RHG, Bouwma IR, Griffioen A, Jones-Walters L, Van Doorn AM (2011) The Pan European ecological network: PEEN. Landscape Ecol 26:311-326

Kandziora M, Burkhard B, Müller F (2013) Interactions of ecosystem properties, ecosystem integrity and ecosystem service indicators-a theoretical matrix exercise. Ecol Indic 28:54-78

Kettunen M, Ten Brink P (2012) Nature, green economy and sustainable development: the outcomes of UN Rio +20 Conference on Sustainable Development. Nat Conserv 2:1-6

Koschke L, Fürst C, Frank S, Makeschin F (2012) A multicriteria approach for an integrated land-cover-based assessment of ecosystem services provision to support landscape planning. Ecol Indic 21:54-66

Lorenz AW, Korte T, Sundermann A, Januschke K, Haase P (2012) Macrophytes respond to reach-scale river restorations. J Appl Ecol 49:202-212

Lovell ST, Johnston DM (2009) Designing landscapes for performance based on emerging principles in landscape ecology. Ecol Soc 14(1):44

Mace GM, Norris K, Fitter AH (2012) Biodiversity and ecosystem services: a multilayered relationship. Trends Ecol Evol 27:19-26

Maes J, Egoh B, Willemen L, Liquete C, Vihervaara P, Schägner JP, Grizzetti B, Drakou EG, La Notte A, Zulian G, Bouraoui F, Paracchini ML, Braat L, Bidoglio G (2012) Mapping ecosystem services for policy support and decision making in the European Union. Ecosyst Serv $1: 31-39$

Maes J, Hauck J, Paracchini ML, Ratamäki O, Hutchins M, Termansen M, Furman E, Pérez-Soba M, Braat L, Bidoglio G (2013) Mainstreaming ecosystem services into EU policy. Environ Sustain 5:128-134

MEA (2005) Ecosystems and human well-being: multiscale assessment, millennium Ecosystem assessment series 4. Island Press, Washington, DC

Merz C, Winkler A, Pekdeger A (2009) Trace elements in streambed sediments of floodplains: consequences for water management measures. Environ Earth Sci 59:25-38

Moss T, Monstadt J (2008) Restoring floodplains in Europepolicy contexts and project experiences. IWA Publishing, London

Mueller M, Pander J, Geist J (2014) The ecological value of stream restoration measures: an evaluation on ecosystem and target species scales. Ecol Eng 62:129-139

Nelson E, Mendoza G, Regetz J, Polasky S, Tallis H, Cameron DR, Chan KMA, Daily GC, Goldstein J, Kareiva PM, Lonsdorf E, Naidoo R, Ricketts TH, Shaw RM (2009) Modeling multiple ecosystem services, biodiversity conservation, commodity production, and tradeoffs at landscape scales. Front Ecol Environ 7(1):4-11 
Nijland H, Menke U (2005) In: Proceedings of the conference 'Flood risk management and multifunctional land use in river catchments'. Mainz, October 2005. Ministry of Transport, Public Works and Water Management, the Netherlands

Pahl-Wostl C (2006) The importance of social learning in restoring the multifunctionality of rivers and floodplains. Ecol Soc 11(1): 10

Palmer MA, Filoso S (2009) Restoration of ecosystem services for environmental markets. Science 325:575-576

Palomo I, Martín-López B, Potschin M, Haines-Young R, Montes C (2013) National Parks, buffer zones and surrounding lands: mapping ecosystem service flows. Ecosyst Serv 4:104-116

Pander J, Geist J (2013) Ecological indicators for measuring stream restoration success. Ecol Indic 30:106-118

Pettifer E, Kay P (2012) The effects of flood defences on riparian vegetation species richness and abundance. Water Environ J 26:343-351

Rey Benayas JM, Newton AC, Diaz A, Bullock JM (2009) Enhancement of biodiversity and ecosystem services by ecological restoration: a meta-analysis. Science 325:1121-1124

Richter BD, Thomas GA (2007) Restoring flows by modifying dam operations. Ecol Soc 12(1):12

Schindler S, Kropik M, Euller K, Bunting SW, Schulz-Zunkel C, Hermann A, Hainz-Renetzeder C, Kanka R, Mauerhofer V, Gasso V, Krug A, Laawars SG, Zulka KP, Henle K, Hoffmann M, Biró M, Essl F, Jaquier S, Balázs L, Borics G, Hudin S, Damm C, Pusch M, van der Sluis T, Sebesvari Z, Wrbka T (2013a) Floodplain management in temperate regions: is multifunctionality enhancing biodiversity? A systematic review protocol. Environ Evid 2:10

Schindler S, Livoreil B, Sousa Pinto I, Araújo R, Zulka KP, Santamaría L, Euller K, Kropik M, Wrbka T (2013b) Final knowledge assessment reports of the 3 case studies and lessons learned. Deliverable 3.1 of the EU-FP7-project KNEU. http://www.biodiversityknowledge.eu/documents?layout= edit\&id=88. Accessed Dec 2013

Scholz M, Stab S, Dziok F, Henle K (2005) Lebensräume der Elbe und ihrer Auen (Band 4 in Konzepte für die nachhaltige Entwicklung einer Flusslandschaft). WeißenseeVerlag, Berlin

Scholz M, Mehl D, Schulz-Zunkel C, Kasperdius HD, Born W, Henle K (2012) Ökosystemfunktionen von Flussauen. Analyse und Bewertung von Hochwasserretention, Nährstoffrückhalt, Kohlenstoffvorrat, Treibhausgasemissionen und Habitatfunktion. Naturschutz und Biologische Vielfalt 124:2

Sedell JR, Richey JE, Swanson FJ (1989) The river continuum concept: a basis for the expected ecosystem behavior of very large rivers. In: Dodge DE (ed) Proceedings of the International Large River Symposium. Canadian Special Publication of Fisheries and Aquatic Sciences 106:49-55

Seppelt R, Müller F, Schröder B, Volk M (2009) Challenges of simulating complex environmental systems at the landscape scale: a controversial dialogue between two cups of espresso. Ecol Model 220:3481-3489

Seppelt R, Fath B, Burkhard B, Fisher JL, Grêt-Regamey A, Lautenbach S, Pert P, Hotes S, Spangenberg J, Verburg PH, van Oudenhovenm APE (2012) Form follows function? Proposing a blueprint for ecosystem service assessments based on reviews and case studies. Ecol Indic 21:145-154

Solín Ľ, Feranec J, Nováček J (2011) Land cover changes in small catchments in Slovakia during 1990-2006 and their effects on frequency of flood events. Nat Hazards 56:195-214

TEEB (2010) In: Kumar P (ed) The economics of ecosystems and biodiversity: ecological and economic foundations. Earthscan, London

Tockner K, Standford JA (2002) Riverine flooplains: present state and future trends. Environ Conserv 29:308-330

Van der Sluis T, Degteva S, Pedroli G (2003) The Pechora River (Russia): reference system for Northwest European Rivers. International conference 'Towards natural flood reduction strategies'. Warsaw, Poland, pp 6-13

Van der Sluis T, Jongman RHG, Bouwma I, Wascher D (2012) Ein Europäischer Biotopverbund - Herausforderungen an den europäischen Kooperations- und Gestaltungswillen. Natur und Landschaft 87:415-419

Vihervaara P, Kumpula T, Tanskanen A, Burkhard B (2010) Ecosystem services-a tool for sustainable management of human-environment systems. Case study Finnish Forest Lapland. Ecol Complex 7:410-420

Welti N, Bondar-Kunze E, Tritthart M, Pinay G, Hein T (2011) Nitrogen dynamics in complex Danube River floodplain systems: effects of restoration. River Syst 20:71-85

Werners S, Flachner Z, Matczak P, Falaleeva M, Leemans R (2009) Exploring earth system governance: a case study of floodplain management along the Tisza river in Hungary. Global Environ Chang 19:503-511 